\title{
The impact of individual and group_based expectations on the self_image and reading comprehension of iranian intermediate efl learners
}

\section{O impacto das expectativas individuais e de grupo sobre a autoimagem e a compreensão de leitura de alunos de Efl iranianos}

\section{El impacto de las expectativas individuales y grupales en la autoimagen y la comprensión lectora de los estudiantes iraníes de nivel intermedio de Efl}

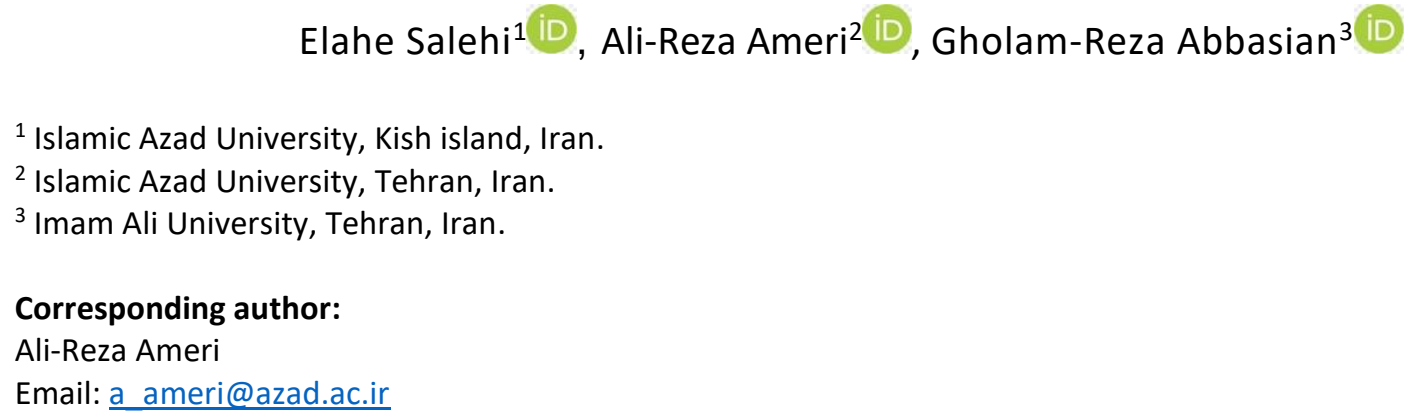

How to cite: Salehi, E., Ameri, A.-R., \& Abbasian, G.-R. (2021). The impact of individual and group_based expectations on the self_image and reading comprehension of iranian intermediate efl learners. Revista Tempos e Espaços em Educação, 14(33), e15298. http://dx.doi.org/10.20952/revtee.v14i33.15298

\begin{abstract}
The study scrutinized the effect of individual and group-based expectations on EFL learners' selfimage and reading comprehension. This study explored the effectuality of individual expectations and group-based expectations in improving self-image and reading comprehension among EFL learners. To do so, 50 out of 120 Iranian EFL learners were chosen as the sample of the study and they were divided into two groups of Individual-based Expectation Instruction and Group-based Expectation Instruction, received five sessions of instruction along with some types of expectations and took two types of reading and self-image tests as a pre- and post-test. In general, the results showed no significant difference between the two groups' mean scores on the post-test of selfimage. The results revealed that the individual expectation group significantly outperformed the group-based expectation group on the post-test of reading comprehension. The findings suggest that using different forms of expectations in language classes can be instrumental in improving the students' self-image and reading comprehension.
\end{abstract}

Keywords: Individual-based expectation. Group-based expectation. High and low self-image. Reading comprehension. Intermediate EFL learner. 


\section{RESUMO}

O estudo examinou o efeito das expectativas individuais e baseadas em grupo na autoimagem dos alunos de EFL e na compreensão de leitura. Este estudo explorou a efetividade das expectativas individuais e expectativas baseadas em grupo na melhoria da autoimagem e compreensão de leitura entre alunos de EFL. Para fazer isso, 50 de 120 alunos de EFL iranianos foram escolhidos como a amostra do estudo e eles foram divididos em dois grupos de Instrução de Expectativa baseada no Individual e Instrução de Expectativa baseada em Grupo, receberam cinco sessões de instrução junto com alguns tipos de expectativas e fez dois tipos de teste de leitura e autoimagem como pré e pós-teste. Em geral, os resultados não mostraram diferença significativa entre os escores médios dos dois grupos no pós-teste de autoimagem. Os resultados revelaram que o grupo de expectativas individuais superou significativamente o grupo de expectativas baseadas em grupo no pós-teste de compreensão de leitura. Os resultados sugerem que o uso de diferentes formas de expectativas nas aulas de línguas pode ser fundamental para melhorar a autoimagem dos alunos e a compreensão de leitura.

Palavras-chave: Expectativa baseada no indivíduo. Expectativa baseada em grupo. Autoimagem alta e baixa. Compreensão de leitura. Aluno intermediário de EFL.

\section{RESUMEN}

El estudio examinó el efecto de las expectativas individuales y grupales sobre la autoimagen y la comprensión lectora de los estudiantes de inglés como lengua extranjera. Este estudio exploró la efectividad de las expectativas individuales y las expectativas grupales para mejorar la autoimagen y la comprensión lectora entre los estudiantes de inglés como lengua extranjera. Para ello, se eligieron 50 de 120 estudiantes iraníes de inglés como lengua extranjera como muestra del estudio y se dividieron en dos grupos de instrucción de expectativas basada en el individuo e instrucción de expectativas en grupo, recibieron cinco sesiones de instrucción junto con algunos tipos de expectativas. y tomó dos tipos de pruebas de lectura y de autoimagen como prueba previa y posterior. En general, los resultados no mostraron diferencias significativas entre las puntuaciones medias de los dos grupos en la prueba posterior de autoimagen. Los resultados revelaron que el grupo de expectativas individuales superó significativamente al grupo de expectativas basadas en el grupo en la prueba posterior de comprensión lectora. Los hallazgos sugieren que el uso de diferentes formas de expectativas en las clases de idiomas puede ser fundamental para mejorar la autoimagen y la comprensión lectora de los estudiantes.

Palabras clave: Expectativa basada en el individuo. Expectativa basada en el grupo. Autoimagen alta y baja. Comprensión lectora. Estudiante de nivel intermedio de inglés como lengua extranjera.

\section{INTRODUCTION}

The concept of self-fulfilling prophecy has done new research on the notion of expectancy in various areas. For example, judicial arena and the relationship between doctor and patient are mong these studies (Rubie-Davies, Hattie, \& Hamilton, 2006). Some scholars believe that the expectations of a person may influence on the prosperity of another person (e.g., Babad, 1993; Kolb \& Jussim, 1994). In this domain of research, Jussim and Eccles (1992) argued that the hypothesis of self-fulfilling prophecy recommends that the instructors' expectations portend students' accomplishment in the near future.

The idea of expectancy was at first scrutinized on instructor expectations in the realm of psychology originating with the work of Tolman's (1938) in the 1930s on the hypotheses of learning about expectancy as they exerted on animal behavior. It is worth mentioning that Tolman (1938) did not concluded that animals and humans make expectancy for producing behaviors they have mastered, and that expectancy can accomplish as motivation to keep the behavior (Zuroff \& Rotter, 1985). 
As Bråten and Strøms $\varnothing$ (2011) stated, more often than not reading is considered as a communicative process, where understanding is the consequence of joint attempts from the writer and the reader. The writer needs to formulate the content in an interpretable way, whereas the reader should mobilize the abilities and knowledge required to understand the passage. Hence, the reader is regarded as the one who is responsible for gaining comprehension. This challenges the interactivity of reading (Bråten \& Strøms $\varnothing, 2011$ ).

Learning strategies and reading strategies are highly interrelated. Moreover, in the learning processes further applicability to reading comprehension is felt to be essential (Roe, 2014). Therefore, several scholars advert to the two notions as one and the same (Roe, 2014). If one cannot to comprehend the passages or tasks, learning and fulfilling of tasks would be very a hard task. As the learners get older, the needs for reading with fluently will be enhanced too. In lower secondary, the topics turn out to be more difficult in comparison to the elementary school, and the amount of theory to be read is very extensive. This is more serious in higher educational terms. Recently, most of the learners confront several years of higher education, and good reading strategies are felt to be necessary (Roe, 2014). For all types of learning, one has to read with fluency and accuracy.

In Rosenblatt's (1985, cited in Lundahl 1998) perspective, comprehension is the consequence of a transaction between the reader and the passage. Rosenblatt (1985) considered reading a text as "an event involving a particular individual and a particular text, happening at a particular time, under particular circumstances, in a particular social and cultural setting, and as part of the ongoing life of the individual and the group" (as cited in Lundahl 1998, p. 194).

The nutshell of an effective education is reading. Without this ability, students are restricted to several significant life activities: they cannot even read a newspaper, read a perfect novel, read directions of a recipe, or read a prescription on the bottle of medication. It should also be mentioned that reading is related to activities in Mathematics, Spelling, Writing as well as the content areas. For those who are not good at reading, college is out of the question and many job opportunities are not reachable since they need some fundamental level of reading or other skill that depends on reading. Lack of reading puts these people at a serious disadvantage in the society (Biancarosa \& Snow, 2004).

Reading skill is fundamental in the process of learning and acquisition of languages. Nowadays there is an overflow of data from various sources including newspapers, books, magazines and electronic sources (Bråten \& Strøms $\varnothing$, 2011). Therefore, it is crucial to go through these types go sources and find out what is required. This needs various skills such as the capability of investigating in the passage, reading electronic sources, and intertextually, along with the understanding of the written passage as well as its vocabularies, phrases, structure, and genres. In a developed community, one needs to have the capability to comprehend and amalgamate data from multiple sources (Bråten \& Strøms $\varnothing, 2011$ ). Obviously, nowadays readers have many requirements. Reading is related to forming vocabularies, phrases, and sentence. For comprehending a specific passage, one has to interact with the text and add meaning to it. In this regard, Roe $(2014$, p. 24) maintained that "reading comprehension is to make meaning of what we read". Cook (2008) argued that that reading takes place in passage, and that the meaning of a text is taken from the prior information saved in the reader's mind. This indicates that it is not sufficient to decode the alphabets and vocabularies. Therefore, one needs accrue information and meaning to what is read. The questions raised here are: how to make meaning of what is read, and how can instructors bolster learners understand what they read? Being an instructor is highly sophisticated and many-sided. They need to make their style of teaching interesting and pertinent for their pupils. In an attempt to teach students something, it is crucial to teach pertinently. Moreover, the instructor needs to take into account various individuals in the classroom. The instructor needs to motivate the learners and make them identify the relevance and benefits of reading so that they could read with comprehension. It is essential that instructors reflect upon several elements such 
as requirements, motivations, features, and resources of their students so that they could reach their learners in an appropriate way. So far, however, there has been little discussion about expectations of EFL learners developed by language teachers. In addition, no research study has been found that surveyed both reading ability and self-image in regard with expectations. The aim of this paper is to determine the impact of individual and group-based expectations in developing reading skill and self-image of EFL learners. To achieve the aims of the study, the two following research questions were formulated.

1. Are individual expectations more effective than group-based expectations in developing selfimage among EFL learners?

2. Are individual expectations more effective than group-based expectations in developing reading ability of EFL learners?

\section{LITERATURE REVIEW}

The theory of Expectancy-value is one of the main stages of motivation as it tries to explain the incentive to pursue a particular action by an individual's expectancy of success and the value that the person appends to this accomplishment (Atkinson, 1964). Moreover, the locus of control affects expectancies (Rotter, 1966). This concept is concerned with whether a person perceives that the outcome of an event lies outside or within his/her control.

The effect of expectancy-value theory can be seen in the motivational approaches of second language. In other words, this theory highlights the value that pupils append to the language, or on their attitudes toward the language. Therefore, to connect expectancy-value theory to research on the notion of self and identity through the value element is significant to be investigated (Brophy, 2009). Likewise, Scott-Jones and Clark (1986) asserted that "Academic achievement is dependent on more than individual abilities and aspirations. The social environment in which learning takes place can enhance or diminish the behaviors that leads to achievement" (p. 523).

In some studies related with expectations and language achievement, different outcomes were drawn. For example, Williams and Burdens' (1999) study showed a tendency among ESL learners in the Britain to discern internal attempt as the compelling justification for success in language learning, assistance from other students and a growing sense of cognition and perception.

Williams, Burden, and Al-Baharna's (2001) study explored the attributions of EFL learners in Bahrain for their academic achievement. The outcomes revealed that support from parents, instructors, and other students as well as positive attitudes toward them and feel confidence on their ability were the possible reasons for students' success.

\section{Reading Comprehension}

Reading is a convoluted skill that requires remarkable time and practice to promote (Lundahl, 1998). The capability to read is not just about decoding a passage. Besides the ability to join the alphabet together, making vocabulary, one is also needs to comprehend what is read. In fact, the individual needs to integrate decoding; the ability of making phrases and sentences, with understanding; the outcome of interpreting non-verbal components (Lundahl, 1998). Gough and Tunmer (1986) regarded reading skill as a formula: Decoding (D) $\times$ Language Comprehension (LC) = Reading Comprehension (RC).

The multiplication is germane to the view that whatever is made to ease reading will multiply the outcome. It should also be noted that if one of the components is missing, the result will be zero. Thus, if there is no comprehending towards what is read, there will be no real reading; there will be no reading comprehension. When this essential aim of reading is obtained, one needs to accrue more components to the reading process in order to become a skilful reader. The subsequent phases on the way to full reading ability are as the following: empathy, motivation, and 
metacognitive ability (Kverndokken, 2012). When a reader handles all these factors, s/he can read fluently.

\section{Reading and Self-image}

Reading familiarity can have impact on the acquisition of knowledge, the future of literacy, and also the improvement of learners' self-image connected to reading skill (Chapman, Tunmer, \& Prochnow, 2000; Stanovich, 1986). Stanovich (1986) believed that for Negative Matthew effects learners who initially experience complexity with reading comprehension, may make those with reading complexities less eager in reading skill and avoid practicing their reading developments as much as they could. It is also claimed that a negative perception of the individuals' ability in reading may lead to a vicious circle so that the learners are not eager in improving their reading ability to the same extent as learners who see themselves good readers (Stanovich, 1986). To Stanovich (1986), this may result in a gap between typical readers and students with reading disabilities, where students with reading difficulties practice less and consequently do not improve their reading skills extensively, while typical readers practice much and develop. The correlation between self-image and reading ability influences the pupil's total school situation and is essential to study (Chapman \& Tunmer, 2003).

\section{Elements that Influence Reading Comprehension}

The motivation to learn and read is an important factor. Some scholars have argued that motivation and involvement are considered as important part of reading ability (Roe, 2014). Thus, in an appropriate reading treatment motivation appears to be vital (Guthrie \& Wigfield, 2000). In order to escalate motivation, it is essential to grantee that learners relate what they read to reality. Moreover, it will be important to provide motivational content, specific reading instructions, and the way to read different texts.

Motivation affects what an individual does as well as the way it is done. Moreover, it provides energy to the process and affects our interaction (Bråten, 2007). Highly motivated learners are struggling to concentrate and focus on reading more than those who are less motivated to read and are able to handle and overcome challenges in the reading process, resulting in reading excessively more than less motivated readers (Bråten, 2007). As excessive reading paves the way for decoding and comprehending of word, it provides information and presents experience in utilizing various reading techniques, it is obvious that excessive reading affects the understanding of reading. In turn, motivation affects excessive reading, and the three elements are interdependent. High motivation for reading results in excessive reading, and the reading itself bolsters promoting the elements that are parts of an appropriate reading comprehension (Wigfield \& Tonks, 2004).

Learners' involvement in reading might be classified into a cognitive dimension, a social dimension, and motivation. Here the purpose of the reading is felt to be very essential. The cognitive dimension indicates that the reader selects the right techniques so that $\mathrm{s} /$ he could understand the passage. The social dimension involves the social aspect of reading and learning, because reading is a personal experience where the motivation needs to come from within the reader, but the knowledge should be boosted in relation with others. Thus, the instructor needs to describe why the learners are to read the passage in question. Moreover, the learners' attitude towards reading is crucial for reading comprehension, and is interrelated with motivation, besides to other elements. Learners who have intrinsic motivation for reading, read all types of passages, including more difficult material that gives insight (Guthrie, Perencevich, Wigfield 2004a). It will be of significant to augment motivation of learners in the process of reading such as selecting a varied and differentiated material in a variety of genres and passage. Utilizing suitable material for the learners' 
level of comprehension, teaching them various reading techniques, and giving feedback that focuses on promotion rather than comparison to others are crucial (Bråten, 2007).

Another significant factor in reading comprehension is the expectation to be able to manage which is also related to motivation. A learner's expectation on his/her reading affects the method to reading and tends to affect the reading outcome. Expectations of managing are germane to how the learners consider their reading comprehension and whether they could solve particular tasks regarding the reading, and is virtually on the basis of previous attainments (Bråten, 2007). Therefore, students with appropriate experiences of reading will build on these experiences and will be expecting to manage well in more reading conditions. They will not be prevented through facing problems, because they will expect to comprehend through time and attempt. They are familiar with different reading techniques that they could to apply when required. Those learners who come up with bad experiences will tend to predict not to be able to understand the passage and make little or no application of reading techniques. Encouragement and positive feedback from others including parents, instructors, and other learners are considered as significant factors for a learner's expectations of managing reading (Bråten, 2007).

There is an inclination that reading motivation reduces during the school years, and several learners lose their willingness and self-confidence that most young students have about the process of reading (Bråten, 2007). Therefore, concentrating on components of the reading process that probably give motivation will be very essential, as emphasizing on word and various reading techniques, and providing positive feedback. How instructors indicate themselves also is significant. An instructor who presents him/herself as a reader, exposing for the learners both what $\mathrm{s} / \mathrm{he}$ likes to read or not to read, as well as how to go through the process of reading will be vital (Kverndokken, 2012). Therefore, the instructor will be a role model as a reader. Creating a 'culture of reading' in the classroom is also very important.

Instructors need to regard the different types of learning styles and intelligences to develop the process of learning. Engaging learners in the teaching and allowing participation in what is taught is helpful for the process of acquisition. As Tornberg (2000) argued, openness in teaching will most likely decrease negative feelings (e.g., stress and anxiety) in learners and on the other hand, have a positive impact on affective elements and motivation, all known as crucial components in successful language learning. It is crucial for instructors to teach languages in a way that will give students pertinent information at the right time and ascertain that all learners feel safe and involved in the classroom to prevent negative affective influence.

\section{METHODODOLOGY}

\section{Participants}

The initial sample included 120 Iranian EFL students. After homogenizing the students, 50 students out of 120 were regarded as the final sample of the study. They were between the ages of 18 and 35 years, all of whom were native speakers of Persian and had at least 4 years of education; they all were at intermediate level of proficiency in English according to the results of Oxford Quick Placement Test (i.e., from 28 and 47).

\section{Instruments}

\section{Oxford Quick Placement Test}

To check the participants' level of English, an Oxford Quick Placement Test (OQPT) was used. Furthermore, using the KR21 formula, the reliability of the test was calculated and reported. To add more, the students' performances was calculated out of 60 and those who were considered as intermediate level were chosen as the final sample of the study. The range score for intermediate was between 28 and 47. 
Table 1. Reliability Statistics for OQPT

\begin{tabular}{|c|c|c|}
\hline Research Instrument & Items & Reliability \\
\hline OQPT & 60 & 0.84 \\
\hline
\end{tabular}

Reading Comprehension Pre-test and Post-test

To measure the students' reading comprehension, a reading test taken from the second edition of "Select Readings" by Lee and Gundersen (2011) was used as the post-test and pre-test of the study. The test was drawn from Select Readings second edition by Lee and Gunderen (2011).

\section{Self-image Test}

The self-image of EFL learners was by Coppersmith Self-Esteem Inventory. Originally this test was a 50-item measure developed by Coppersmith's (1967). Furthermore, the test went under some changes by Rydin (1978) in order to apply it on adult students. The modified version contains 58 items. In this inventory test the students select "like me" or "unlike me" that each option is equal to "yes" or "no" answer. In order to check the validity, the current instrument was evaluated by two university professors specialized in language testing and applied linguistics. Besides, the reliability of the test was gauged thorough Cronbach alpha.

\section{Data Collection Procedures}

Prior to the initiation of the study, in order to homogenize the students and select the intermediate level students, an OQPT was administered. Then, based on the OQPT, 50 out of 120 EFL learners were selected as the final sample of the study. All participants of the study were randomly assigned to either Individual-based Expectation Instruction or Group-based Expectation Instruction, with 25 learners in the individual-based Expectation Instruction group and 25 in the Group-based Expectation Instruction group. Students in both groups were informed that the goal of the study was not to test them but rather scaffold them enhance ther reading comprehension and self-image. Participants in both groups took a pre-test of reading comprehension and a pre-test of self-image, then the two groups received five sessions of instruction along with some sorts of expectations provided by the teacher. A post-test of reading comprehension and a post-test of selfimage was administered immediately after the treatment.

\section{Data Analysis}

All scores were entered into SPSS (statistical package for social sciences), version 22, and a range of descriptive and inferential statistics were computed. The following analyses were utilized in order to reply the two research questions. At first, descriptive statistics for the OQPT, reading pre-test and post-test, and self-image test were computed. Second, two independent sample t-test for the first and second research questions of the study were performed.

\section{FINDINGS}

\section{Exploring First Research Question}

An independent t-test was run to compare the individual and group-based expectations groups' means on the post-test of self-image in order to probe the first null-hypothesis. Based on the results displayed in Table 2 it can be claimed that the group-based group ( $M=80.56, S D=7.19)$ had a slightly higher mean on the post-test of self-image than individual expectation group ( $M=$ 78.64, SD = 8.52). 
Table 2. Descriptive Statistics; Post-test of Self-Image by Groups

\begin{tabular}{|c|c|c|c|c|c|}
\hline & Group & N & Mean & Std. Deviation & Std. Error Mean \\
\hline \multirow{2}{*}{ Self-Image } & Individual & 25 & 78.64 & 8.52 & 1.70 \\
\cline { 2 - 6 } & Group & 25 & 80.56 & 7.19 & 1.43 \\
\hline
\end{tabular}

The results of the independent $t$-test $(\mathrm{t}(48)=.861, \mathrm{p}=.394, \mathrm{r}=.123$ representing a weak effect size) (Table 3 ) indicated that there was not any significant difference between the two groups' mean scores on the post-test of self-image. Thus it can be claimed that the first null-hypothesis was supported.

The negative $95 \%$ lower bound confidence interval of -2.56 indicated that the difference between the two groups' means on the post-test of self-image could have been zero. Thus the above mentioned conclusion as no significant difference between the two groups' means was correctly made. It should also be noted that the assumption of homogeneity of variances was met (Levene's $F=.393, p=.534)$. That was why the first row of Table 2, i.e. "Equal variances assumed" was reported.

Table 3. Independent Samples t-test; Post-test of Self-Image by Groups

\begin{tabular}{|c|c|c|c|c|c|c|c|c|c|}
\hline & \multicolumn{2}{|c|}{$\begin{array}{l}\text { Levene's Test } \\
\text { for Equality of } \\
\text { Variances }\end{array}$} & \multicolumn{7}{|c|}{ t-test for Equality of Means } \\
\hline & \multirow[t]{2}{*}{$\mathrm{F}$} & \multirow[t]{2}{*}{ Sig. } & \multirow[t]{2}{*}{$\mathbf{T}$} & \multirow[t]{2}{*}{ Df } & \multirow[t]{2}{*}{$\begin{array}{l}\text { Sig. (2- } \\
\text { tailed) }\end{array}$} & \multirow[t]{2}{*}{$\begin{array}{c}\text { Mean } \\
\text { Difference }\end{array}$} & \multirow[t]{2}{*}{$\begin{array}{l}\text { Std. Error } \\
\text { Difference }\end{array}$} & \multicolumn{2}{|c|}{$\begin{array}{c}95 \% \text { Confidence } \\
\text { Interval of the } \\
\text { Difference }\end{array}$} \\
\hline & & & & & & & & Lower & Upper \\
\hline $\begin{array}{c}\text { Equal variances } \\
\text { assumed }\end{array}$ & .39 & .53 & .86 & 48 & .39 & 1.92 & 2.23 & -2.56 & 6.40 \\
\hline $\begin{array}{c}\text { Equal variances not } \\
\text { assumed }\end{array}$ & & & .86 & 46.68 & .39 & 1.92 & 2.23 & -2.56 & 6.40 \\
\hline
\end{tabular}

Figure 1. Mean on post-test of self-image by groups

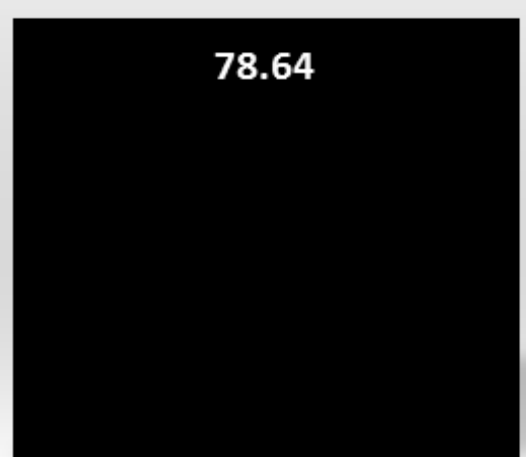

Individual Expectation

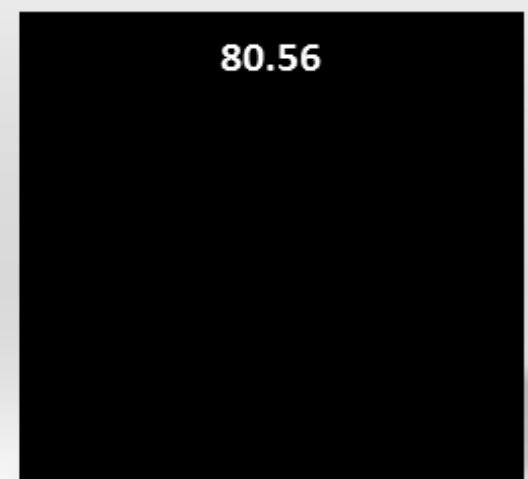

Group-Based Expectation

\section{Exploring Second Research Question}

An independent t-test was run to compare the individual and group-based expectations groups' means on the post-test of reading comprehension in order to probe the second nullhypothesis. Based on the results displayed in Table 4 it can be claimed that the individual expectation group $(M=16, S D=3.42$ ) had a higher mean on the post-test of reading comprehension than group-based expectation group $(M=11.68, S D=5.37)$. 
Table 4. Descriptive Statistics; Post-test of Reading Comprehension by Groups

\begin{tabular}{|l|l|l|l|l|l|}
\hline & Group & $\mathbf{N}$ & Mean & Std. Deviation & Std. Error Mean \\
\hline \multirow{2}{*}{ Reading comprehension } & Individual & 25 & 16.00 & 3.42 & .68 \\
\cline { 2 - 7 } & Group & 25 & 11.68 & 5.37 & 1.07 \\
\hline
\end{tabular}

The results of the independent $t$-test $(t)(40)=3.38, p=.002, r=.515$ representing a large effect size) (Table 5) indicated that the individual expectation group significantly outperformed the group-based expectation group on the post-test of reading comprehension. Thus it can be claimed that the second null-hypothesis was rejected.

It should also be noted that the assumption of homogeneity of variances was not met (Levene's $F=7.28, p=.010$ ). That was why the second row of Table 5, i.e. "Equal variances not assumed" was reported.

Table 5. Independent Samples t-test; Post-test of Reading comprehension by Groups

\begin{tabular}{|c|c|c|c|c|c|c|c|c|c|}
\hline & \multicolumn{2}{|c|}{$\begin{array}{l}\text { Levene's Test } \\
\text { for Equality of } \\
\text { Variances }\end{array}$} & \multicolumn{7}{|c|}{ t-test for Equality of Means } \\
\hline & \multirow[t]{2}{*}{$\mathrm{F}$} & \multirow[t]{2}{*}{ Sig. } & \multirow[t]{2}{*}{$T$} & \multirow[t]{2}{*}{ Df } & \multirow[t]{2}{*}{$\begin{array}{l}\text { Sig. (2- } \\
\text { tailed) }\end{array}$} & \multirow[t]{2}{*}{$\begin{array}{c}\text { Mean } \\
\text { Difference }\end{array}$} & \multirow[t]{2}{*}{$\begin{array}{l}\text { Std. Error } \\
\text { Difference }\end{array}$} & \multicolumn{2}{|c|}{$\begin{array}{l}\text { 95\% Confidence } \\
\text { Interval of the } \\
\text { Difference }\end{array}$} \\
\hline & & & & & & & & Lower & Upper \\
\hline $\begin{array}{c}\text { Equal variances } \\
\text { assumed }\end{array}$ & 7.28 & .01 & 3.38 & 48 & .00 & 4.32 & 1.27 & 1.75 & 6.88 \\
\hline $\begin{array}{c}\text { Equal variances } \\
\text { not assumed }\end{array}$ & & & 3.38 & 40.75 & .00 & 4.32 & 1.27 & 1.74 & 6.89 \\
\hline
\end{tabular}

Figure 2. Mean on post-test of reading comprehension by groups

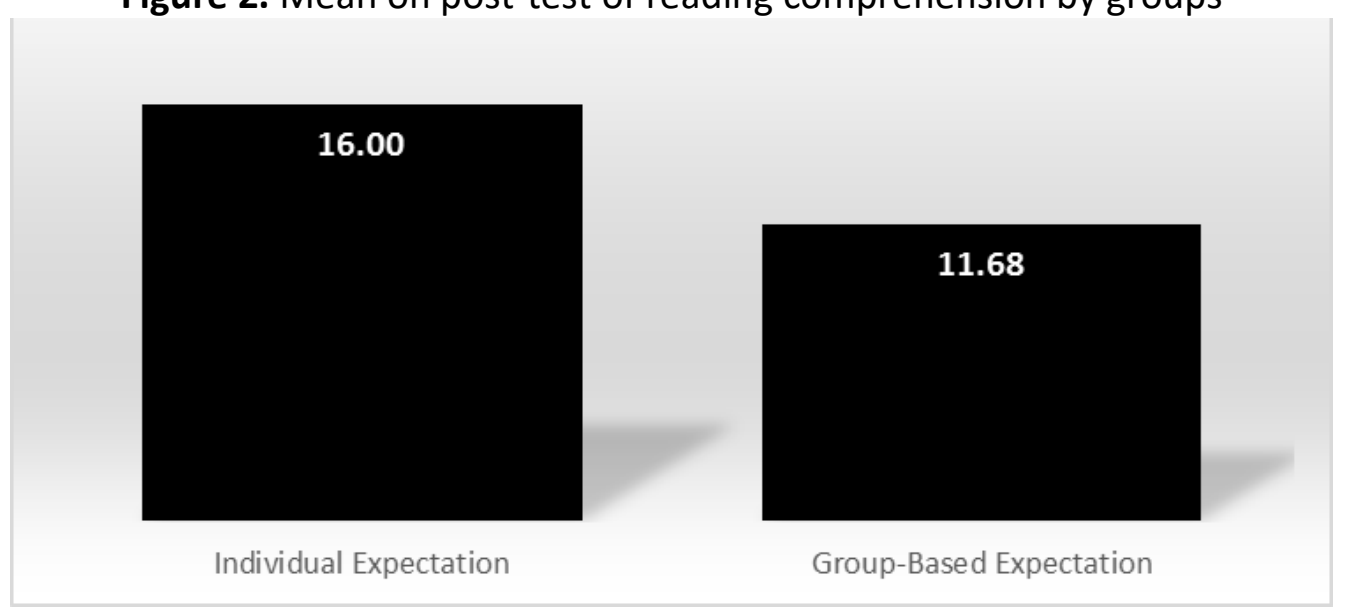

\section{DISCUSSION}

This study was conducted to examine the impact of individual and group-based expectations in developing self-image and reading ability of EFL learners. The samples were selected from University. The present research explored two hypotheses: The first hypothesis was: Individual expectations are not more effective than group-based expectations in developing self-image among EFL learners. The analysis exhibited that there was not any significant difference between the individual and group-based expectations' mean scores on the post-test of self-image The results, in general, indicated the impact of individual and group-based expectations on the self-image development among EFL learners, however, no significant difference between these two types of expectations was observed. Therefore, the first null hypothesis is supported. As a matter of fact, the two hypotheses of this study can add a new dimension to this domain of research, since no similar 
study has investigated the effect of expectations on self-image and reading ability like this study in order to compare and contrast their results with the findings of the present paper. Therefore, the discussion should be taken into account cautiously.

The findings provide support for Babad's (1993) claim which represented the role of expectations in the achievement of students in language learning. The findings of this study are also congruent with the results of Kolb and Jussim (1994) that reported the beneficial impacts of expectations on the students' language achievement and build up the learners' perception and awareness of themselves or their self-image. In addition, the findings are partially in line with Jussim and Eccles (1992). The researchers believed that the expectations from teachers can boost the cognition of learners' mental activity and this may lead to academic accomplishment and learners' self-mage improvement.

Moreover, the results of this study lend support to the claims of Williams and Burdens' (1999) study in which the learners who received help from other learners and their classmates got more understanding and confidence of their own capabilities. Besides, the results are also consistent with the perspectives of Scott-Jones and Clark (1986) that completing the task types collaboratively can improve students' self-image and their assurance to do different activity.

The second hypothesis posited: Individual expectations are not more effective than groupbased expectations in developing reading ability of EFL learners. The analysis of the data represented that the individual expectation had a remarkable performance than the group-based expectation group on the post-test of reading skill. Consequently, in light of the findings of this study, the second null hypothesis is rejected and the findings point to the superiority of individualbased expectation over group-based expectation in enhancing reading comprehension.

In other words, the analysis of the collected data showed expectations, both individually and collaboratively, were effective in developing reading ability. However, the results represented that individual expectation instruction was more effective than group -based expectation instruction in boosting the reading comprehension of EFL learners. In regard with the fact that no previous study was done in regard with individual and group-based expectation instructions and their impacts on self-image and reading comprehension, it can be said that the findings of this study are partially in line with the claims of Rosenthal and Jacobson's (1968) that expectations have positive effects on learning language skills. The findings of the study are also consistent with the concept of selffulfilling prophecy developed by Rosenthal and Jacobson (1968) by which the instructor has particular idea about individuals or groups of pupils and it gives an opportunity to achieve those expectations.

In terms of the beneficial effects of expectations on developing reading ability, the results of this study are partially in line with the findings of Guthrie and Wigfield, 2000, Kverndokken, 2012, and Roe, 2014. These studies represented that motivation, expectations, and metacognitive ability are important factors in enhancing reading skill. Furthermore, the results are also consistent with the findings of Bråten's (2007) and Wigfield and Tonks's (2004) study that expectation and motivation give energy to the individuals in order to have a better performance in the process of understanding a text. They concluded that high motivation and expectation lead to excessive reading and consequently better reading comprehension. The results are also consistent with Bråten's (2007) study which reported the critical role of expectation in reading comprehension so that positive feedback from others like instructors and other learners are truly essential for being success in language learning especially reading comprehension.

\section{CONCLUSION, IMPLICATIONS, AND LIMITATIONS}

According to the felt gap in previous research, the necessity for continuation of previous studies, and the need to explore the issues under investigation that we as researchers and instructors had in mind, this paper was written to report the outcomes of the study that aimed at 
discerning the impact of expectations on self-image and reading comprehension. The findings of this study indicated that both individual and group-based expectation instructions impacted selfimage and reading comprehension. Although the individual expectation-based instruction was not more effective than group-based expectations in regard with self-image, individual expectationbased instruction was more beneficial in developing reading comprehension.

Furthermore, the findings of this study can imply that teachers should not independently concentrate on the strategies of reading in order to develop EFL learners' reading comprehension. To develop reading skill, all the suitable factors need to be considered (e.g., Psychological factors). The incorporation of individual and group-based expectations as a valuable ingredient that has a psychological influence on the language learning of pupils needs more investigation. This study can also be helpful for English teachers in making individual and group-based expectations as well as improving self-image and reading comprehension.

This study has a number of methodological limitations that must be taken into consideration when generalizing the findings. First, this study was conducted with a small groups of intermediate EFL learners over the course of only one semester. Further studies with more pupils over longer periods of time are required to completely figure out the impacts of expectations on self-concepts and language skills. Second, the students' academic program prevented the study from including a delayed post-test in this study to represent that the effect of individual or group-based expectations is permanent. The other limitation of the study might be the dual role of a researcher and a teacher. It is not viable to assert that this had thoroughly no effect on the study, while the researchers did their best to control everything objectively.

Authors' Contributions: Elahe Salehi: conception and design, acquisition of data, analysis and interpretation of data, drafting the article, critical review of important intellectual content. Ali-Reza Ameri: conception and design, acquisition of data, analysis and interpretation of data, drafting the article, critical review of important intellectual content. Gholam-Reza Abbasian: conception and design, acquisition of data, analysis and interpretation of data, drafting the article, critical review of important intellectual content. All authors have read and approved the final version of the manuscript.

Ethics Approval: Not applicable.

Acknowledgments: Not applicable.

\section{REFERENCES}

Atkinson, J. (1964). An introduction to motivation. Princeton, Van Nostrand.

Araujo, A., \& Silva, I. P. (2020). Maker culture and educational robotics in physics teaching: developing an automated traffic light in high school. Journal of Research and Knowledge Spreading, 1(1), e11654.

Babad, E. (1993). Pygmalion: 25 years after interpersonal expectations in the classroom. In P. D. Blank (Ed.), Interpersonal expectations: Theory, research, and application. Studies in emotional and social interactions (pp. 125153). Cambridge, UK: Cambridge University Press.

Biancarosa, G., \& Snow, C. E. (2004). Reading next-A vision for action and research in middle and high school literacy: $A$ report from Carnegie Corporation of New York. Washington, DC: Alliance for Excellent Education.

Bråten, I. (red.). (2007). Leseforståelse. Lesing i kunnskapssamfunnet - teori og praksis. Oslo: Cappelen Akademisk Forlag.

Bråten, I. \& Strøms $\varnothing$, M. (2011). Measuring strategic processing when students read multiple texts. Metacognition and Learning, 6(2), 111-130.

Brito, R. dos S., Prado, J. R., \& Nunes, C. P. (2017). As condições de trabalho docente e o pós-estado de bem-estar social. Revista Tempos e Espaços em Educação, 10(23), 165-174.

Brophy, J. (2009) Connecting with the big picture. Educational Psychologist, 44: 147-157.

Cook, V. (2008). Second Language Learning and Language Teaching. Oxford: Oxford University Press. 
Chapman, J. W. \& Tunmer, W. E. (2003). Reading difficulties, reading-related self-perceptions, and strategies for overcoming negative self-beliefs. Reading \& Writing Quarterly: Overcoming Learning Difficulties, 19, 5-24.

Chapman, J. W., Tunmer, W. E. \& Prochnow, J. E. (2000). Early reading-related skills and performance, reading selfconcept, and the development of academic self-concept: A longitudinal study. Journal of Educational Psychology, 92, 703-708.

Gough, P. \& Tunmer, W. (1986). Decoding, reading, and reading disability. Remedial and Special Education, 7, 6-10.

Guthrie, J. T. \& Wigfield, A. (2000). Engagement and motivation in reading. Handbook of reading research, 3, 403-422.

Guthrie, J. T., Wigfield, A. \& Perencevich, K. C. (2004a). Scaffolding for motivation and engagement in reading. In: J. T. Guthrie, A. Wigfield \& K. C. Perencevich (Eds). Motivating reading comprehension: Concept oriented reading instruction (pp. 55-86). Mahwah, NJ: Erlbaum.

Jussim, L., \& Eccles, J. (1992) Teacher expectations: Construction and reflection of student achievement. Journal of Personality and Social Psychology, 63, 947-961.

Kolb, K. J., \& Jussim, L. (1994). Teacher expectations and underachieving gifted children. Roeper Review, 17, 26-30.

Kverndokken, K. (2012). 101 måter å lese leseleksa på. Bergen: Fagbokforlaget.

Lundahl, B. (1998). Engelsk Språkdidaktik. Texter, kommunikation, språkutveckling. Lund: Studentlitteratur AB.

Roe, A. (2014). Lesedidaktikk - etter den første leseopplæringen. Oslo: Universitetsforlaget.

Rosenthal, R., \& Jacobson, L. (1968). Pygmalion in the classroom: Teacher expectation and pupils' intellectual development. New York, NY: Holt, Rinehart \& Winston.

Rotter, J. (1966) Generalized expectancies for internal versus external control of reinforcement. Psychological Monographs, 80, 1-28.

Rodrigues, B. M., Santos, J. E. B., \& Vasconcelos, C. A. (2020). Conceptions of undergraduate students in Chemistry on the use of interactive interfaces in and for the activities developed in the distance course. Journal of Research and Knowledge Spreading, 1(1), e11649

Rubie-Davies, C. M., Hattie, J., \& Hamilton, R. (2006). Expecting the best for students: Teacher expectations and academic outcomes. British Journal of Educational Psychology, 76(3), 429-444.

Santos, J. E. B. (2020). Cartographic narratives: the teaching of mathematics and ICT. Journal of Research and Knowledge Spreading, 1(1), e11645

Scott-Jones, D., \& Clark, M. L. (1986). The school experiences of black girls: The interaction of gender, race or ethnicity, and socioeconomic status. Phi Delta Kappan, 67(7), 520-526.

Silva, C. V. S., \& Santos, G. O. (2020). Digital interfaces: a methodological proposal as a strategy of teaching and learning in Mathematics classes. Journal of Research and Knowledge Spreading, 1(1), e11651.

Stanovich, K. E. (1986). Matthew effects in reading: Some consequences of individual differences in the acquisition of literacy. Reading Research Quarterly, 21, 360-406.

Tolman, E. C. (1938). The determiners of behavior at choice point. Psychological Review, 45: 1-41.

Tornberg, U. (2000). Språkdidaktikk. (2.nd edition). Bergen: Fagbokforlaget.

Wigfield, A. \& Tonks, S. (2004). The development of motivation for reading and how it is influenced by CORI. In: J.T. Guthrie, A. Wigfield \& K.C. Perencevich (Eds). Motivating reading comprehension: Concept oriented reading instruction. (pp. 249272). Mahwah, NJ: Erlbaum.

Williams, M. \& Burden, R. (1999). Students' developing conceptions of themselves as language learners. The Modern Language Journal, 83,193-201.

Williams, M., Burden, R. \& Al-Baharna, S. (2001). Making sense of success and failure: the role of the individual in motivation theory. IN Dörnyei, Z. \& Schmidt, R. (Eds.), Motivation and second language acquisition. Manoa, HI, University of Hawai'i.

Zuroff, D. C., \& Rotter, J. B. (1985). A history of the expectancy concept in psychology. In J. B. Dusek (Ed.), Teacher. expectancies (pp. 9-36). Hillsdale, NJ: Erlbaum.

Received: 14 January 2021 | Accepted: 19 February 2021 | Published: 27 February 2021 

unrestricted use, distribution, and reproduction in any medium, provided the original work is properly cited. 